\title{
PERISTIWA CAMPUR KODE DALAM CERAMAH K.H. ANWAR ZAHID PADA ACARA BERSIH DESA DI LAMPUNG
}

\author{
Oleh: \\ Emi Auni Faridah \\ (Pendidikan Bahasa dan Sastra Indonesia, Fakultas Keguruan dan Ilmu Pendidikan, Universitas PGRI \\ Adi Buana Surabaya) \\ Emiaunifaridah@gamail.com \\ Ira Eko Retnosari, S.S., M.Pd. \\ (Dosen Program Studi Pendidikan Bahasa dan Sastra Indonesia, Fakultas Keguruan dan Ilmu Pendidikan, \\ Universitas PGRI Adi Buana Surabaya) \\ Ira@unipasby.ac.id
}

\begin{abstract}
Code mixing is a theory that studies about the mixing of two or more languages. Code mixing can be defined as the use of two or more language codes by speakers, which one of the codes used is only a word fragment. The object of this research was speech video by K.H. Anwar Zahid and the focus of the study in this research was the form, type, and function of code mixing in the speech of K.H. Anwar Zahid in the event of bersih desa in Lampung. The reason to choose people of Tunggal Jaya village, district of Banjar Agung, regency of Tulang Bawang, city of Lampung, because $80 \%$ of the people were transmigrant. Hence, it was easier to find the code mixed used in Lampung. The method used in this research was descriptive method by using qualitative research approach. To collect the data, in this research used listen and matching method, it was listening to the language used by K.H. Anwar Zahid from the video and match of this video. Thus, the data analysis techniques in this research was collecting data, finding the form, type, and function of code mixing, classifying, reducing, describing, and interpreting it. Based on the results of the study that had been done, there were five codes mixing found and those were: words, phrases, baster, repetition words, and clauses that used in every speech. Most of data was found in this research was a code mixing in the form of words. The kind of code mixing that had been found in this research were: had a function as repetition, insertion of the sentence, and often found as the function of specification conversation
\end{abstract}

\section{PENDAHULUAN}

Bahasa dipergunakan oleh manusia dalam segala aktivitas kehidupan. Dengan demikian, bahasa merupakan hal yang paling hakiki dalam kehidupan manusia. Reaching Koen (dalam Aslinda dan syafyahya 2010:2) menyatakan bahwa hakikat bahasa bersifat mengganti, individual, kooperatif, dan sebagai alat komunikasi. Bahasa termasuk bagian terpenting dalam kehidupan, tanpa bahasa masyarakat tidak akan bisa saling berinteraksi.
Saat ini, ilmu pengetahuan dan teknologi sangatlah cepat berkembang, sama halnya dengan ilmu kebahasaan yang semakin beragam, banyak ahli-ahli yang ingin mendalami ilmu tentang kebahasaan, mengingat bahwa bangsa Indonesia adalah bangsa yang kaya akan keanekaragaman budaya dan juga keanekaragaman bahasa. Ilmu kebahasaan pun juga semakin luas, seperti sosiolinguistik. Sosiolinguistik adalah bagian dari ilmu linguistik yang fokus keilmuannya dalam bidang kebahasaan, Appel (dalam Chaer dan Agustina, 1995:3) mengatakan bahwa 
sosiolinguistik memandang bahasa sebagai sistem sosial dan sistem komunikasi serta merupakan bagian dari masyarakat dan kebudayaan tertentu, dalam hal ini ilmu sosiolinguistik dapat memandang dari mana seseorang berasal, atau seperti apa kehidupan sosial seseorang hanya melalui cara seseorang tersebut berinteraksi dengan orang lain melalui bahasanya.

Namun demikian, disisi lain masalah-masalah kebahasaan pun seringkali muncul, ini karena semakin pesatnya ilmu pengetahuan sehingga masyarakatpun ingin mengikuti perkembangan zaman melalui pekembangan ilmu dan teknologi tersebut. Contohnya saja masalah kedwibahasaan, yang saat ini tak jarang dijumpai masyarakat-masyarakat yang mampu menggunakan dua bahasa atau lebih dalam bertutur.

Hal tersebut dapat menimbulkan masalah kebahasaan lainnya seperti muculnya peristiwa campur kode. Dalam hal ini, seringkali dijumpai fenomenafenomena kebahasaan, karena bahasa merupakan wadah yang pas dalam mengungkapkan apa yang ingin disampaikan, baik itu ide, pesan, atau bahkan untuk menyampaikan informasi. Dalam sisi keagamaan, bahasa juga digunakan sebagai sarana untuk berdakwah kepada orang lain seperti halnya bahasa yang digunakan untuk menyampaikan petuah melalui ceramah agama.

Thelander (dalam Aslinda dan Syafyahya.2010) berpendapat campur kode adalah peristiwa tutur yang menggunakan klausa atau frase campuran, dan masingmasing frasa atau kalusa tidak lagi mendukung fungsi masing-masing. Tindak bahasa yang demikian kita sebut campur kode." Penguasaan dua bahasa atau lebih dapat mempermudah seseorang dalam tindak komunikasi, misalnya saja pada objek kajian yang digunakan dalam penelitian ini yaitu penelitian tentang peristiwa campur kode dalam ceramah
K.H. Anwar Zahid pada acara bersih desa di Lampung.

Salah satu faktor mengapa terjadi peristiwa campur kode dalam ceramah tersebut sekaligus alasan kenapa saya memilih mengamati ceramahnya yang berlangsung di Lampung tepatnya di Desa Dwi Warga Tunggal Jaya. Di Lampung, kemungkinan untuk terjadinya peristiwa campur kode sangatlah besar karena Lampung terkenal dengan penduduknya yang rata-rata bukan penduduk asli (masyarakat pendatang). Delapan puluh empat persen penduduknya adalah pendatang, kebanyakan penduduknya berasal dari Sunda, Minangkabau, Jawa, juga kelompok etnis seperti Bali, Batak, dan bengkulu. Hal ini lah yang menarik perhatian saya untuk meneliti video ceramahnya K.H. Anwar Zahid yang berlangsung di Lampung karena tentu saja kemungkinan untuk beliau menggunakan bahasa campuran sangatlah besar dan hal inilah yang menjadi alasan dalam penelitian ini.

\section{METODE PENELITIAN}

Berdasarkan rumusan masalah dan tujuan penelitian, maka penelitian ini menggunakan pendekatan kualitatif. Creswell (dalam Iskandar, 2009) mengemukakan bahwa pendekatan kualitatif adalah suatu proses penelitian dan pemahaman yang berdasarkan pada metodologi yang menyelidiki suatu fenomena sosial dan masalah manusia. Metode penelitian yang digunakan adalah metode deskriptif. Hal ini disebabkan karena data yang terkumpul dan dianalisis dipaparkan secara deskriptif. Alasan lain bahwa penelitian ini adalah penelitian kulitatif adalah penyajian hasil penelitian ini berupa penjabaran tentang objek, dan pengumpulan data dengan latar alamiah. Dalam penelitian ini, teknik pengumpulan data yang digunakan adalah teknik simak padan, tenik simak dilakukan dengan melihat dan menyimak rekaman video 
ceramah K.H. Anwar Zahid. Tidak hanya melihat tetapi juga menyimak tuturan yang sesuai dengan permasalahan yang dibuat, yaitu bentuk campur kode, jenis campur kode, dan fungsi campur kode. Setelah itu dilakukan metode padan.

Selanjutnya, akan dilakukan analisis data, seperti yang dipaparkan oleh Sujana (dalam Iskandar, 2009) menyatakan analisis data kualitatif bertolak dari fakta/informasi di lapangan. Fakta atau informasi tersebut kemudian diseleksi dan dikembangkan menjadi pertanyaanpertanyaan yang penuh makna, maka langkah-langkah analisis data yang dilakukan antara lain. (1) mengumpulkan data, (2) menemukan data yang berupa wujud, fungsi, dan jenis campur kode, (3) mengklasifikasi data, (4) mereduksi data, (5) mendekripsikan data, menginterpretasi data.

\section{HASIL DAN PEMBAHASAN Wujud Campur Kode dalam Ceramah K.H. Anwar Zahid pada Acara Bersih Desa di Lampung}

Suwito (1983:78-80) berpendapat bahwa bentuk campur kode terbagi menjadi enam bentuk yaitu (1) penyisipan unsur-unsur yang berwujud kata, (2) penyisipan unsur-unsur yang berwujud frasa, (3) penyisipan unsur-unsur yang berwujud bentuk baster, (4) penyisipan unsur-unsur yang berwujud perulangan kata, (5) penyisipan unsur-unsur yang berwujud ungkapan atau idiom, dan (6) penyisipan unsur-unsur yang berwujud klausa. Dalam penelitian ini ditemukan data yang berupa wujud campur kode berbentuk kata, frasa, baster, perulangan, dan klausa, adapun pemaparan wujud campur kode yang ditemukan yaitu sebagai berikut.

\section{(1) Campur kode berwujud kata}

Dalam penggalan ceramah di bawah ini, ditunjukkan penutur menggunakan unsur campur kode yang berwujud kata. adapun datanya akan diuraikan sebagai berikut

"Salam hormat, salam taqdim saya haturkan kepada para alim ulama, para khoba'ib, para tuan guru, para kiyai, para ibu nyai, masyayikh, asatid, dan para sesepuh, pejabat pemerintah dalam semua tingkatannya"

Tuturan tersebut merupakan salah satu contoh wujud campur kode, dalam tuturan tersebut, terdapat kata yang mengandung unsur campur kode yang berupa kata. Kata taqdim, khoba'ib, masyayikh, dan asatid merupakan kata yang berasal dari bahasa Arab. Dalam hal ini sudah jelas terlihat bahwa terdapat pencampuran suatu unsur bahasa ke dalam bahasa lain yang dalam hal ini disebut campur kode yang berwujud kata.

\section{(2) Campur kode berwujud frasa}

Frasa adalah gabungan dua kata atau lebih yang sifatnya tidak prediktif, gabungan itu dapat rapat dan dapat renggang (Suwito, 1983). Dalam penggalan ceramah di bawah ini menunjukkan penutur menggunakan unsur campur kode yang berwujud kata. Adapun data-datanya akan diurakan sebagai berikut.

"Segala puja dan puji hanya milik allah rabbul'alamin yang telah melimpahkan karunia dan nikmatnya kepada kita sekalian."

Dalam tuturan tersebut terlihat adanya peristiwa campur kode, kata robbul'alamin adalah unsur dari bahasa Arab yang artinya "Tuhan Semesta Alam" kata tersebut merupakan bentuk dari frasa yang tersusun dalam bahasa Arab, disisipikan kedalam unsur bahasa Indonesia. Dikatakan sebagai frasa karena dilihat dari segi gramatikalnya yang membentuk satuan makna yang diwujudkan dalam bahasa Arab, sehingga dapat dinyatakan kata-kata tersebut menjadi tanda adanya peristiwa campur kode yang berwujud frasa .

\section{(3) Campur kode berwujud baster}


Suwito

(1983:78-80)

mengemukakan bahwa baster merupakan hasil perpaduan dua unsur bahasa yang berbeda membentuk satu makna. Unsur tersebut bisa saja gabungan dari bahasa Indonesia dan bahasa Ingris, bahasa Indonesia dan Jawa, atau bahasa Indonesia dengan bahasa Arab. Akan tetapi bentuk tersebut tetap membentuk makna tertentu.

Dalam penelitian ini, juga ditemukan beberapa bentuk campur kode yang berwujud baster. Baik itu perpaduan antara bahasa Indonesia dengan Inggris, bahasa Indonesia dengan Jawa, ataupun bahasa Indonesia dan Arab. Adapun datadata yang dimaksud akan dikemukakan sebagai berikut.

“.., apa maksudnya ilmu entut, tolong didengar! dalam dunia perentutan, ilmu entut itu ilmu yang dimana-mana jadi fitnah itu ilmu entut,.. “"

Dalam tuturan tersebut, juga terdapat bentuk campur kode yang berwujud baster. Bentuk baster tersebut adalah ilmu perentutan yang artinya ilmu perkentutan. Dikatakan wujud baster karena kata tersebut memang gabungan dari dua unsur bahasa yaitu bahasa Indonesia dan Jawa. Kata tersebut merupakan penanda bahwa dalam tuturan tersebut terdapat peristiwa campur kode.

\section{(4) Campur kode berwujud perulangan}

Chaer (2012:182) berpendapat bahwa reduplikasi adalah proses morfemis yang mengulang bentuk dasar, baik secara keseluruhan, secara sebagian (persial), maupun dengan perubahan bunyi.

Dalam peristiwa campur kode, tidak jarang dijumpai bentuk-bentuk kata yang termasuk dalam kata perulangan (reduplikasi) yang berunsurkan bahasa lain dan menjadi penanda adanya pencampuran dua unsur yang disebut campur kode. Adapun data-data yang telah ditemukan sebagai bentuk campur kode yang berwujud perulangan kata adalah sebagai berikut.
"Kaya tapi sakit-sakiten banyak juga orang yang secara ekonominya miskin tapi hidupnya bahagia, melarat tapi sehat."

Dalam tuturan tersebut terdapat bentuk perulangan yang berunsurkan bahasa Jawa yaitu kata sakit-sakiten yang artinya sakit-sakitan. Kata tersebut termasuk dalam jenis perulangan berimbuhan yaitu perulangan kata dasar yang sekaligus mendapat imbuhan.

(5) Campur kode berwujud klausa

Achmad dan Abdullah (2012) berpendapat bahwa klausa ialah satuan gramatikal yang disusun oleh kata dan atau frasa yang mempunyai satu predikat. Sedangkan menurut Chaer dalam bukunya klausa adalah satuan sintaksis berupa runtutan kata-kata berkonstruksi predikatif. Artinya didalam konstruksi itu ada komponen berupa kata atau frasa, yang berfungsi sebagai predikat dan yang lain berfungsi sebagai subjek, sebagai objek dan keterangan. Dalam penelitian ini juga ditemukan wujud campur kode berupa klausa, adapun contohnya sebagai berikut.

"Ini semua kurang tepat, "uwes mas, ora ngiro tak ombe kok! Wes ben"”,

Dalam tuturan tersebut, terdapat unsur bahasa Jawa yang berupa klausa yang tersisip ke dalam bahasa Indonesia. unsur tersebut adalah uwes mas,ora ngiro tak ombe kok! Yang artinya sudah mas, tidak akan saya minum. Kata tersebut merupakan unsur klausa pasif, kata tak ombe yang artinya saya minum menjadi subjek dan predikat sedangkan mas menjadi objeknya.

Jenis Campur Kode dalam Ceramah K.H. Anwar Zahid pada Acara Bersih Desa di Lampung

Tidak hanya wujud campur kode, dalam penelitian ini juga ditemukan jenis campur kode, jenis yang ditemukan dalam video ceramah K.H. Anwar Zahid ada tiga jenis yaitu jenis campur kode ke dalam, campur kode ke luar, dan campur kode 
campuran. adapun pemaparan mengenai jenis campur kode sebagai berikut.

\section{(1) Jenis campur kode ke dalam}

Campur kode ke dalam adalah jenis kode yang menyerap unsur-unsur bahasa daerah yang sekerabat. Umpamanya gejala campur kode pada peristiwa tururan bahasa Indonesia terdapat di dalamnya unsurunsur bahasa daerah seperti bahasa Sumbawa, Lombok, Bima, bahasa Jawa, dan sebagainya.

Dalam penelitian ini, juga ditemukan beberapa data yang termasuk ke dalam jenis campur kode ke dalam (inner code mixing). Yang akan dipaparkan sebagai berikut.

"Kaya tapi sakit-sakiten, banyak juga orang yang secara ekonominya miskin tapi hidupnya bahagia, melarat tapi sehat."

Dari data tersebut, dapat dikatakan sebagai campur kode ke dalam karena tuturan-tuturan tersebut merupakan sebuah unsur bahasa Indonesia yang tersisipi unsur dari bahasa lain. Dari data tersebut, sudah terlihat bahwa unsur bahasa Indonesia dalam tuturan di atas terdapat penyispan bahasa lain, yaitu unsur bahasa daerah atau bahasa Jawa. Oleh sebab, itu data-data tersebut diklasifikasikan ke dalam jenis campur kode ke dalam (inner code mixing) atau dalam artian suatu bahasa yang disisipi unsur bahasa yang berasal dari dalam unsur bahasa itu sendiri dalam hal ini unsur bahasa Indonesia disisipi ragam bahasanya sendiri yaitu bahasa Jawa.

\section{(2) Jenis campur kode ke luar}

Jendre (dalam http://www.ejurnal.com/2017/03/campur-kode-dalamjurnal-ilmiah-fkip.html) berpendapat bahwa campur kode keluar adalah campur kode yang menyerap unsur- unsur bahasa asing. Misalnya, dalam peristiwa campur kode pada pemakaian bahasa Indonesia terdapat sisipan dari bahasa asing seperti bahas Inggris, bahasa Arab, bahasa Jepang, bahasa Cina, dan lain sebagainya.
Dalam penelitian ini, juga terdapat peristiwa campur kode keluar (outer code mixing) baik itu berupa kata, frasa, perulangan, kata, ataupun klausa. Adapun data yang ditemukan adalah sebagai berikut.

"Segala puja dan puji hanya milik allah rabbul'alamin yang telah melimpahkan karunia dan nikmatnya kepada kita sekalian"

Tuturan dalam data tersebut, terdapat peristiwa campur kode luar. Yaitu pencampuran atau penyerapan unsur-unsur bahasa asing ke dalam bahasa Indonesia. Dalam hal ini unsur-unsur bahasa asing tersebut, merupakan unsur bahasa Arab yang disisipkan ke dalam unsur-unsur bahasa Indonesia baik itu berwujud kata, frasa, perulangan kara, atau berwujud klausa. Hal tersebut menjadi penanda adanya peristiwa campur kode luar yang ditandai dengan kode-kode bahasa Arab yang diserap oleh unsur-unsur bahasa Indonesia.

\section{(3) Jenis campur kode campuran}

Campur kode yang di dalam (mungkin klausa atau kalimat) telah menyerap unsur bahasa Sumbawa/Lombok/Jawa (bahasa daerah) dan bahasa asing. Jendre (dalam http://www.e-jurnal.com/2017/03/campurkode-dalam-jurnal-ilmiah-fkip.html) lebih tegas mengatakan bahwa campur kode campuran merupakan unsur serapan yang diterima oleh bahasa penyerap dengan pembagian menjadi dua bagian seperti (inner dan outer code mixing) telah pula dilakukan.

Dalam penelitian ini, juga ditemukan beberapa tuturan yang menunjukkan pencampuran antara bahasa daerah dan bahasa asing ke dalam unsur bahasa Indonesia, dalam hal ini peristiwa tersebut yang dinamakan campur kode campuran. adapun data yang telah ditemukan adalah sebagai berikut.

“.., islam yang bagaimana, keliru kadang-kadang gara-gara otaknya 
tercuci karena aliran-aliran yang ndak jalur kehadirotul rosull muhammad

sollahlahwalaihiwassalam, ati-ati dulur gausah kemakan fitnah, adu domba yang macem-macem."

Data tersebut, dikatakan sebagai campur kode campuran karena tuturantuturan dalam data tersebut terdapat penyisipan kode-kode yang berunsurkan bahasa daerah dan bahasa asing, bahasa daerah yang tersisipkan di dalam tuturan tersebut adalah bahasa Jawa dan bahasa asingnya adalah bahasa Arab. Hal ini menjadi penanda bahwa dalam tuturantuturan tersebut telah terjadi peristiwa campur kode campuran, karena bahasa Indonesia yang menjadi bahasa utamanya tersisipi kedua unsur-unsur bahasa tersebut, baik itu dalam wujud kata, frasa, perulangan kata, ataupun klausa.

Fungsi Campur Kode dalam Ceramah K.H. Anwar Zahid pada Acara Bersih Desa di Lampung

Dan data terakhir yang ditemukan dalam penelitian ini adalah data fungsi campur kode. Gumpers (dalam http://www.e-jurnal.com/2017/03/campurkode-dalam-jurnal-ilmiah-fkip.html)

berpendapat bahwa peristiwa campur kode terjadi tentu karena adanya beberapa fungi yang ingin dicapai. Fungsi campur kode yang ditemukan dalam penelitian ini ada tiga fungsi, yaitu (1) fungsi perulangan, (2) fungsi penyisip kalimat, dan (3) fungsi spesifik lawan tutur. Adapun pemaparan fungsi campur kode yaitu sebagai berikut.

\section{(1) Fungsi perulangan}

"Malah saat ini yang punya kedudukan tinggi yang pangkatnya mentereng itu tidurnya nggak bisa lelap, turune gak tanek blas."

Dalam peristiwa campur kode, tentu memiliki fungsi-fungsi tertentu, Gumpers (dalam

http://anaksastra.blogspot.co.id/2009)

berpendapat bahwa dalam campur kode yang berfungsi sebagai perulangan adalah pengulangan suatu pesan dengan menggunakan kode lain, baik secara literal atau dengan sedikit perubahan. Sama halnya seperti data-data tersebut yang memiliki fungsi sebagai perulangan. Dalam data tersebut dapat dilihat bahwa ada pesan-pesan yang diulang dengan kode lain untuk mempertegaskan pesan yang ingin disampaikan, baik itu berupa kata, frasa, ataupun klausa.

\section{(2) Fungsi penyisip kalimat}

"Saya ulang karena jama'ahnya belum fokus merhatiin yang nyuguhin minum."

Data yang digaris bawahi tersebut, menunjukkan fungsi campur kode sebagai penyisip kalimat yang mengisyaratkan telah terjadinya peristiwa campur kode. Baik itu tersisipi kode lain yang berupa kata, frasa, maupun klausa, akan tetapi penyisipan tersebut dianggap sebagai penanda telah terjadinya campur kode dengan tersisipnya unsur-unsur dua bahasa ataupun lebih.

\section{(3) Fungsi spesifik lawan tutur}

"Ini semua kurang tepat, "uwes mas, ora ngiro tak ombe kok! Wes ben"”

Dari data tersebut, dapat dikatakan bahwa fungsi campur kode tersebut adalah sebagai fungsi spesifikasi lawan tutur. Sehingga dapat diketahui latar belakang penutur dan lawan tuturnya. Hal ini dilakukan oleh penutur karena penutur bertujuan ingin mengakrabkan diri kepada lawan tutur sehingga dipilihlah penggunaan campur kode yang bertujuan agar suasana menjadi lebih santai dan sekaligus sebagai pemancing candaan dalam keakraban tersebut.

Dari hasil penelitian tersebut terdapat tiga jenis data yang ditemukan yaitu berupa wujud campur kode, jenis campur kode, dan wujud campur kode. wujud campur kode yang ditemukan adalah campur kode berwujud kata, frasa, perulangan, baster, dan klausa. Dari wujud campur kode yang telah ditemukan 
tersebut, wujud campur kode yan lebih dominan dan banyak ditemukan dalam ceramah K.H. Anwar Zahid adalah wujud campur kode berupa kata. Sedangkan, jenis campur kode yang ditemukan ada tiga jenis yaitu campur kode ke dalam, campur kode keluar dan campur kode ke dalam. Akan tetapi jenis yang paling dominan ialah jenis campur kode ke dalam. Tidak hanya wujud dan jenis saja dalam penelitian ini juga ditemukan tiga fungsi campur kode yaitu fungsi perulangan kata, fungsi pelengkap kalimat, dan fungsi spesifikasi lawan tutur. Dari ketiga fungsi yang telah ditemukan, fungsi campur kode yang paling dominan ialah fungsi spesifikasi lawan tutur.

\section{SIMPULAN}

Berdasarkan hasil analisis dan pembahasan mengenai peristiwa campur kode dalam ceramah K.H. Anwar Zahid pada acara bersih desa di Lampung dapat disimpulkan, wujud campur kode yang ditemukan berdasarkan hasil dari penelitian ini ada lima wujud. Yaitu $80 \%$ wujud campur kode berupa kata, 5\% wujud campur kode berupa frasa, 2\% wujud campur kode berwujud baster, 10\% wujud campur kode perulangan, dan 3\% wujud campur kode berupa klausa.

Dalam penelitian ini, juga terdapat tiga jenis campur kode yang ditemukan dalam penelitian ini, berdasarkan hasil analisis yang telah dilakukan, data yang di dapatkan terkait jenis campur kode, yaitu 90\% data berjenis campur kode ke dalam, $3 \%$ data berjenis campur kode campuran, dan 7\% data berjenis campur kode ke luar.

Tidak hanya wujud dan jenis campur kode, hasil penelitian ini juga ditemukan tiga fungsi campur kode. Berdasarkan hasil penelitian dapat disimpulkan bahwa fungsi campur kode dalam ceramah K.H. Anawar Zahid pada acara bersih desa di Lampung. Terdapat tiga macam fungsi campur kode yang ditemukan dengan hasil $85 \%$ data berfungsi sebagai spesifikasi lawan tutur,
$10 \%$ data berfungsi sebagai penyisip kalimat, dan $5 \%$ data berfungsi sebagai perulangan.

Dari pemaparan tersebut, dapat disimpulkan bahwa campur kode yang paling banyak ditemukan adalah campur kode berwujud kata. Jenis campur kode yang mendominasi dalam penelitian ini adalah campur kode ke dalam, dan fungsi campur kode yang banyak ditemukan adalah campur kode yang berfungsi sebagai spesifikasi lawan tutur.

\section{DAFTAR PUSTAKA}

Aslinda dan Syafyahya. 2010. Pengantar Sosiolinguistik. Bandung: PT Refika Aditama

Arif, Mohamad Faisol dkk. "Campur Kode Dalam Jurnal Ilmiah FKIP UNTAN Guru Membangun Edisi Desember 2014"Jurnal Hasil Riset, Online, 56, http://www.ejurnal.com/2017/03/campur-kodedalam-jurnal-ilmiah-fkip.html, diunduh 24 Januari 2018 pukul 21:54.

Chaer, Abdul. 2012. Linguistik Umum. Jakarta: Rineka Cipta.

Chaer, Abdul, dan Leonie Agustina. 1995. Sosiolinguistik Perkenalan Awal. Jakarta: PT Rineka Cipta.

Djajasudarma, Fatimah. 2006. Metode Linguistik. Bandung: PT. Refika Aditama.

HP, Achmad dan Alek Abdullah. 2012. Linguistik Umum. Jakarta: Penerbit Erlangga.

Iskandar. 2009. Metodologi Penelitian Kualitatif. Jakarta: Gaung Persada Press. 
Suwito. 1983. Pengantar Awal

Sosiolingusitik.

Surakarta: Henry Offset.

http://anaksastra.blogspot.co.id/2009.

Diakses

pada 07 Agustus 2017 